\title{
Critical thinking development by using the implicit content of songs ${ }^{1}$
}

\section{Desarrollo del pensamiento crítico a través del uso del contenido implícito de canciones}

\author{
Daniel Antonio Arias Casas ${ }^{2}$ \\ Universidad Pedagógica y Tecnológica de Colombia - Tunja \\ dariascasas@gmail.com
}

Received: September 24, 2017

Accepted: November 30, 2017

How to cite this article (APA, 6th ed.): Arias-Casas, D. (2018). Critical thinking development by using the implicit content of songs. Enletawa Journal, 11(1), 13-32

\begin{abstract}
This study aimed to reveal the critical thinking development process of third English level students at a Languages Institute in a public University in Colombia when using the implicit content of songs through problem-based activities. A set of problem-based activities became the mechanism to achieve the prime goal of this study. The instruments from which the data was collected were video-recordings, focus group interviews and students' artifacts. The findings revealed three main aspects according to the purpose of the research: the teacher must set up appropriate conditions to engage students in a critical thinking process, the participants' critical thinking process can vary according to the different perspectives and activities implemented in the classroom and songs in university contexts can be used purposefully to activate thinking in the learning process.
\end{abstract}

Key words: Songs, Critical Thinking and Problem-based learning.

1 Research Report.

2 Daniel Antonio Arias Casas holds a Master degree in Language Teaching from Universidad Pedagógica y Tecnológica de Colombia. He is currently working as a full time teacher at Universidad Pedagógica y Tecnológica de Colombia - Tunja. His research interests are related to interculturality, ESL, assessment and critical pedagogy. 


\section{Resumen}

Este estudio tuvo como objetivo revelar el proceso de desarrollo de pensamiento crítico de los estudiantes de tercer nivel de inglés en una Universidad pública en Colombia cuando se utiliza el contenido implícito de canciones y actividades basadas en problemas. Una serie de actividades basadas en problemas se convirtió en el mecanismo para lograr el objetivo principal del estudio. Los instrumentos para la recolección de los datos fueron: videos, entrevista focalizada y artefactos de los estudiantes. Los resultados de la investigación revelaron tres aspectos principales relacionados con el propósito de la investigación: El docente debe establecer condiciones apropiadas para involucrar a los estudiantes en un proceso de pensamiento crítico. El proceso de pensamiento crítico de los estudiantes puede variar según las diferentes perspectivas y actividades implementadas en el aula. Finalmente, las canciones en contextos universitarios pueden ser usadas intencionalmente para activar el pensamiento en el proceso de aprendizaje.

Palabras clave: Canciones, Pensamiento crítico y Aprendizaje basado en problemas. 


\section{Introduction}

Being aware that English teachers are directly committed to the promotion of an integral education that seeks not only to guide students' personal formation but also to project them to a globalized world, it is important to devise pedagogical strategies that allow English as a Foreign Language (EFL) students to learn through a number of different methodologies that respond to a demanding and changing world.

Songs have been part of a bunch of strategies employed by teachers when their students look for new vocabulary and expressions. Fonseca, Toscano, and Wermke (2011) define music as a powerful aid in language learning in which music is the combination of speech, melodies and natural interaction. Therefore, it might be possible to use songs as an enormous source in the development of a critical thinking process since students are pioneers of change and future of any society. According to Beyer (as cited in Iakovos, 2011, p. 82), critical thinking entails the ability to gather, evaluate, and use information effectively. It also involves thinking skills such as interpreting, understanding, evaluating different points of views, judging, posing and solving problems. It has also been defined as "a combination of mental processes and affective dispositions that allow learners to achieve their purposes with a strong capacity of self-monitoring" (Pineda, 2003, p. 40).

In that sense, the problem evidenced in the classroom that consequently fostered the implementation of this study was in terms of the existing need to focus the English classroom activities on critical thinking dynamics and the way English teachers can use songs differently by extracting their inner richness. That means to move from a common and very predictive use of songs, such as improving pronunciation, vocabulary and idiomatic expressions, to a more meaningful way of teaching and learning by opening new opportunities in the reconstruction of meaning. Thus, the main question of this study was: How does the use of the implicit content of songs through problem-based activities reflect the critical thinking development of third English students in a Languages Institute at a public university?

\section{Theoretical Framework}

\section{Music in EFL contexts}

The concepts of messages and meaning transmitted by songs have been a great tool in learning, but much more useful in EFL scenarios where definitely, language learning is the principal purpose in communication. Music can also improve several language skills such as listening and speaking and it can improve students' attention and memory (Hill and Robinson, 2003). Paquette and Rieg (2008) agree by claiming that during the act of listening to songs, learners develop the four basic language skills: reading, writing, listening, and speaking. In practice, the listener activates the brain and when listening to a song with close attention and awareness, the four basic skills can be activated too. Likewise, Kennedy (2014) suggests that "using songs in the classroom to teach a foreign language is an effective way of improving pronunciation, vocabulary, linguistic competence and confidence, even grammar" (p. 296). In that sense, 
a musical learning environment might generate interest, encourage creativity, and establish conditions for a positive learning process.

There is another aspect to consider when talking about songs in the classroom. Cultural diversity can also be approached through songs, because students learn about other positions and musical tendencies, which means learning about others (Kendall, 1996). This quote helps us understand the importance of the diversity and the respect that must exist when observing the varied worlds around us. Students can express their personal interests, types of music they listen to and a multiple of opinions that contribute to change the dynamic in the classroom.

\section{Critical thinking}

Critical thinking (CT) is becoming a prime goal of student and teacher education (Birjandi and Bagherkazemi, 2010). Nurius (1995) states that critical thinking is the tendency of searching for proofs and reflecting on the context. The assertions presented here are the ability of understanding concepts and criticizing considering the evidence in an objective manner. Critical thinking in the EFL classroom is nowadays a required component of a well-rounded education. University scenarios are ideal to set a number of opportunities to address language learning, mainly, because students can construct critical thinking and need to manage certain skills in the foreign language to show their particular points of view. Consequently, songs employed and critical thinking in the classroom can be combined to understand the social and cultural issues that are always presented in the participants' daily life. Students and even teachers may deploy different visions and interpretation of the contents of songs in meaningful activities, considering that a suitable situation that favors the analysis of contents is the first condition to generate a critical thinking process.

\section{Problem-based learning related to critical thinking}

CT processes require some kinds of mechanisms to be somehow activated into a setting. One of those ways to see how CT is emerging is through the use of problem-based learning (PBL), which is an approach for learning that contributes to develop reflective thinking in students (Yuen, 2011). Problem-based learning (PBL) is particular because the central point of study is a problem rather than a mere subject. It is designed for free inquiry, group collaboration, self-directed, selfmonitoring, and self-regulation. A relevant factor that some research has focused on nowadays tends to explain the importance of metacognition in the implementation of CT skills. Halpern (1998) declares that metacognition refers to the use of skills to improve CT. Students need to deploy a certain kind of skills such as: monitoring, checking, ensuring about accuracy and deciding about mental effort.

Given what was said above regarding the vast use of music in human activities and its useful application in EFL environments, is necessary to integrate the boundaries of songs at university EFL levels with problem based activities to evidence what are those opinions, points of view and arguments, dwelling inside the students' minds, that are part 
of a great thinking process, particular for each student.

\section{Research Design}

The intention with this study was to reveal the different EFL students' CT development process, focusing on the importance of using music in the current classroom bearing in mind that songs may shape the ways of thinking from a number of degrees. A qualitative paradigm seemed to provide the basis to achieve that end. Patton (2002) defines the characteristics of a qualitative study in terms of understanding the particularities and interactions that occur in a context. It is to understand human behavior and experience by which people construct meaning (Bogdan and Biklen, 1998), and it seeks to capture the essential characteristics of a field (Richards, 2009). Likewise, this study followed the action research approach because the main intention is to implement some actions that modify the current reality in relation with the critical thinking process that students exert and the different use that English teachers can attribute to music in the classroom. Coghlan (2004) mentions the necessary process to follow when doing action research, the cyclical fourstep process where the main constructs refer to acting more than thinking about action: (1) Planning: Based on the reality and the focus of the intervention a set of activities are designed and coordinated; (2) Action: This is the time for implementing the activities and having a closer contact with the immediate context; (3) Evaluation: This component lets understand and reflect upon the complete process of planning and implementing; (4) Further planning: The cycle starts again based on the new findings.

\section{Research setting and participants}

This study was carried out with an intermediate group of English students from a public University in Colombia. The course was one of the four mandatory foreign language levels that students were expected to take before graduation. They belonged to different careers and shared the same objective in terms of learning the language. The course involved in the process of this research dedicated 4 hours of English per week aiming to develop the learning of the language in 64 hours during the academic semester. The group of students in this project consisted of 21 students, 13 men and 8 women of third English level who were aged from 17 to 30 years old. They were selected purposefully because their English level could contribute to the development of the project. They had an intermediate English level that was developed throughout their personal experiences and the previous two levels offered by the University.

\section{Data collection procedure}

The instruments used to collect data were video recordings, student's artifacts (charts, papers and classrooms materials), a focus group interview and a final survey. Observation through video recording was a required tool to gather suitable information in order to analyze what happened during the implementation of the project. According to Hubbard and Miller (1999) observation through video recording becomes a relevant instrument when the researcher has a clear objective when recording. For that reason, video recording was used to analyze the classrooms dynamics during some 
specific moments in the implementation of the activities. In addition to the video recording, students' artifacts were important in this research because the participants could reflect upon the emergent issues displayed on songs from various contexts, times, and personal conditions that were reflected when writing and speaking during the sessions. A focus group interview had a specific role in this project taking into consideration their usefulness in research and to get information we could not listen to without getting inside students' minds about the experiences during the development of the project, and due to the amount of students and the practicality for data gathering, as well. Hubbard and Miller (1999) remark that surveys become enriching when the purpose of the researcher is to know what is behind the evident and visible, in that sense, the intention with this final instrument was to have a closer point of view about students' beliefs, thoughts and deeper opinions facing some cultural and social aspects when listening and thinking about songs.

\section{Instructional design}

The implementation of the project comprised two general moments: Introduction and development.

Introduction. During the introductory moment, the students received training for them to know the components and basic characteristics of a CT process, and at the same time, to learn useful expressions about how to give opinions and ask for information in English. This first introductory session considered the following aspects: CT dispositions, relevant aspects in $\mathrm{CT}$, metacognitive strategies and English expressions and vocabulary. The first aspect was where the students had contact with a chart (Critical dispositions self-rating form) that might provide suitable evidence of the current dispositions students had before the implementing the project. In the second, students needed to be conscious about the usefulness of critical thinking in education. "Critical thinking involves evaluating a situation, problem, or argument and choosing a path of investigation that leads to the best possible answers" (Feldman, 2009, p.10). After recognizing critical thinking as a conscious activity in learning, students needed to identify themselves with a variety of strategies to make the thinking process far more meaningful. This might be possible through metacognitive strategies. According to Pineda (2003), the metacognitive strategies should be taught, and the role of the teacher becomes crucial, given that the teacher is the one who provides conditions and helps students to become aware of their process. In order to facilitate communication in the English class and a real use of the language, students were given a bank of questions and expressions to use during the implementation of the activities.

Development. Regarding the second moment, when students knew the questions and phrases they could use to support ideas and express their thoughts, we moved to the development of five sessions. The sessions were framed under the principles of problembased learning and critical thinking cognitive skills. Barrow's model was relevant to create a scenario to develop PBL activities (as cited in Tseng, 2008). From this perspective three important phases composed the basis for PBL: 


\begin{tabular}{|c|c|}
\hline 1. Starting a new point & Students are assigned a task \\
\hline 2. Problem Follow-up & Students reassess a problem \\
\hline 3. Conclusion of the problem & $\begin{array}{c}\text { Students develop their } \\
\text { conclusions }\end{array}$ \\
\hline
\end{tabular}

\section{Table 1. PBL steps}

The pedagogical intervention entailed Interpretation, analysis, explanation, the three main phases in PBL. Students were given a problematic situation taken from the content of a song, based on some questions and specific activities, they gave opinions and responses to the questions which were classified according to the CT skills proposed by Facione (2013): components. etc. Through the process and in order to communicate more in English than in Spanish, they were allowed to use code switching, so they can feel free when providing opinions. The following chart presents the pedagogical intervention with all of its

Session: 100 minutes

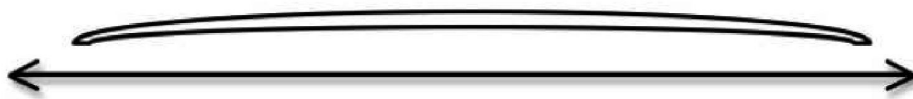

CT Components

Bloom (as cited in Puthikanon, 2009 and Facione, 2013)

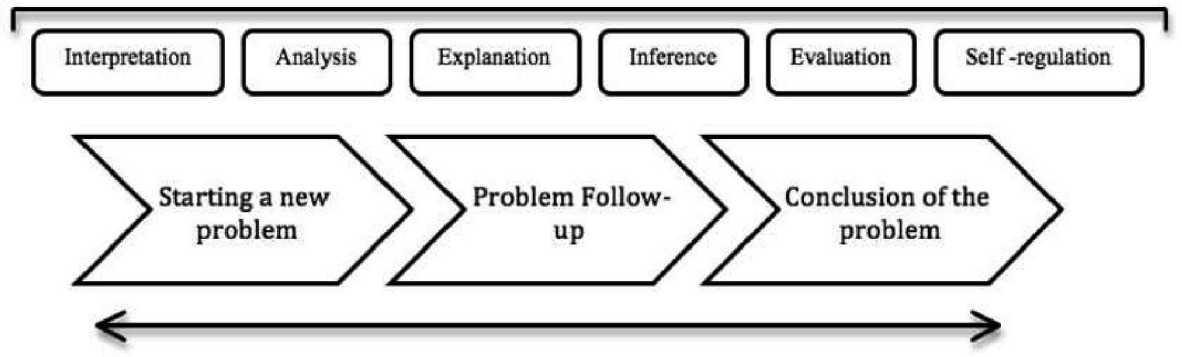

Chart 1. Pedagogical Intervention Phases 


\section{Findings}

This process of analysis was framed under the four basic fundamental activities proposed by Freeman (1990):

\begin{tabular}{|l|l|}
\hline Naming & Extracting the data according to the research purpose. \\
\hline Grouping & Categories that have emerged from data. \\
\hline $\begin{array}{l}\text { Finding } \\
\text { relationships }\end{array}$ & $\begin{array}{l}\text { Finding relationships is the process in which the categories } \\
\text { build meaningful bridges among them to identify patterns that } \\
\text { conduct to the answer asked at the beginning of the process. }\end{array}$ \\
\hline Displaying & $\begin{array}{l}\text { Visibly compare what is behind the interpretation in an } \\
\text { organized matter. }\end{array}$ \\
\hline
\end{tabular}

\section{Table 2. Process of analysis}

The combination of an apriori approach and a grounded theory was also necessary due to the kind of instruments and the purpose of the research. Grounded approach has to do with the development of theory from data through a process of making comparisons and coding (Strauss as cited in Bell and Waters 2010, p. 18). Additionally, during this process the creation of sense appeared, it was necessary to identify insights, compare them and test them in such a way they transformed into categories and as a result the final theory (Hayes as cited in Bell and Waters 2010, p. 19). Conversely, a priory approach refers to that information that was fixed into those predetermined categories according to the purpose of the research (Freeman, 1999). After conducting the procedure of naming, grouping, finding relationships and displaying, the following category and sub-categories emerged in regards to the research question and main objective: 


\begin{tabular}{|c|c|c|c|}
\hline $\begin{array}{l}\text { RESEARCH } \\
\text { QUESTION }\end{array}$ & $\begin{array}{c}\text { MAIN } \\
\text { CATEGORY }\end{array}$ & $\begin{array}{c}\text { SPECIFIC } \\
\text { OBJECTIVES }\end{array}$ & $\begin{array}{c}\text { SUB- } \\
\text { CATEGORIES }\end{array}$ \\
\hline \multirow{3}{*}{$\begin{array}{l}\text { How does the use of } \\
\text { the implicit content } \\
\text { of songs through } \\
\text { problem-based } \\
\text { activities reflect the } \\
\text { critical thinking } \\
\text { development of third } \\
\text { English students in a } \\
\text { Languages Institute } \\
\text { at a public university? }\end{array}$} & \multirow{3}{*}{$\begin{array}{l}\text { Ask me and } \\
\text { you will know } \\
\text { my mind. }\end{array}$} & $\begin{array}{l}\text { To explore the effects } \\
\text { of the class conditions } \\
\text { set up by the teacher } \\
\text { on the students' } \\
\text { critical thinking } \\
\text { development. }\end{array}$ & $\begin{array}{l}\text { Give me } \\
\text { alternatives } \\
\text { to think } \\
\text { differently. }\end{array}$ \\
\hline & & $\begin{array}{l}\text { To evidence students' } \\
\text { critical thinking level } \\
\text { by the resolution of } \\
\text { problems extracted } \\
\text { from the content of } \\
\text { songs. }\end{array}$ & $\begin{array}{l}\text { Critical thinking } \\
\text { ladder. }\end{array}$ \\
\hline & & $\begin{array}{l}\text { To determine the } \\
\text { contributions of } \\
\text { music combined } \\
\text { with problem-based } \\
\text { activities in the } \\
\text { critical thinking } \\
\text { development of } \\
\text { second English } \\
\text { level students at the } \\
\text { Languages Institute. }\end{array}$ & $\begin{array}{l}\text { Music: one word } \\
\text { many routes. }\end{array}$ \\
\hline
\end{tabular}

Table 3. Categories

Ask Me and You Will Know my Mind

During the whole process of implementation and based on the data gathered from the instruments, it was evident the congruence of facts found in each one of the five sessions. It was revealed the importance of the use of questions and situational activities where the participants of this research study were expected to give opinions and propose particular solutions and points of view. The following are some examples of the questions that enabled students to generate a starting point in the process of thinking critically during the sessions. 


\section{Extract 1:}

Teacher: What is your musical tendency?

Student 1: Mmm, Sweet Cheater. (14:48)

Teacher: Why do you like it?

Student 1: His songs are very nice. (15:15)

Video recording

\section{Extract 2:}

Teacher: ¿Qué podríamos decir? It's about love?

Student 3: Love broke. Broke?. (33:50)

Video recording

The aspects highlighted before were part of the main category observed during the implementation of the activities in which the act of asking and answering became the most important vehicle to observe critical thinking development. From this perspective, it was completely necessary to observe an issue and then based on a question, try to look for the answer.

\section{Give me Alternatives to Think Differently}

First, this subcategory presents the results of the analysis of data in accordance with the conditions that students needed to think critically based on a specific purpose when using songs. Training was the first important condition because it created the basis for the students to conduct and develop the activities. At the beginning of the process most of the participants reported to have a high critical thinking disposition based on a CT dispositions self-rating form designed by Facione (2013).

\section{Disposición al pensamiento crítico \\ Formato de Auto-evaluación}

Nombre:

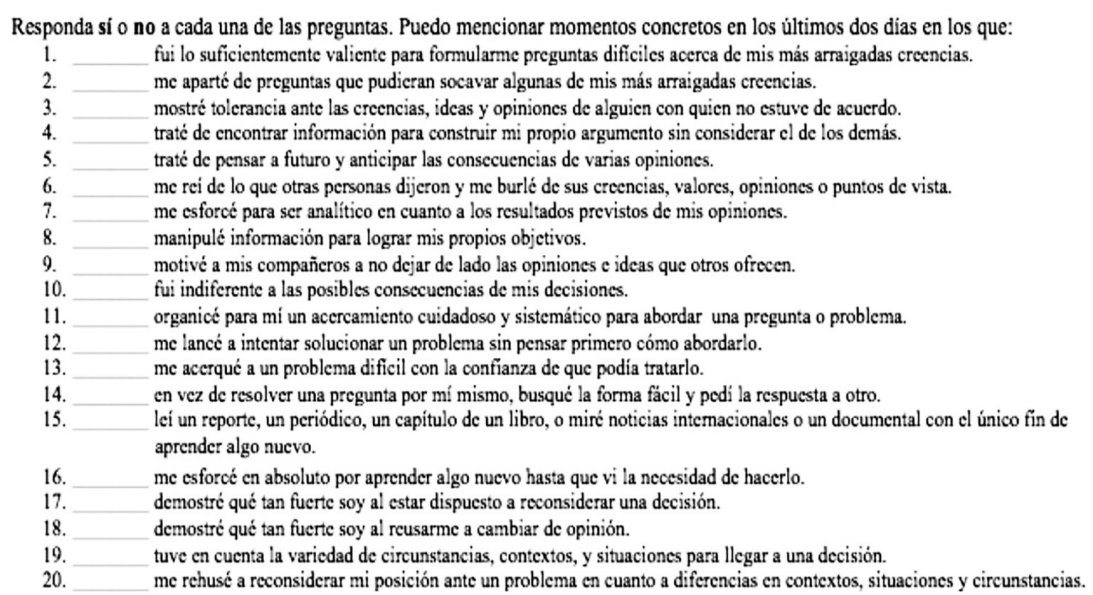

Total

Si usted ha respondido honestamente este formato de auto-evaluación le puede ofrecer un estimado apropiado de lo que usted piensa ha sido su disposición frene al pensamiento critico en los últimos dos dias.

Asigne 5 puntos a cada Sí en números impares y a cada NO en números pares.

Si su total es 70 o más, usted califica como positiva su disposición al pensamiento crítico durante los últimos dos dias. Puntajes de 50 o menos indica una calificación que es contraria al pensamiento critico durante los últimos dos días. Puntajes entre 50 y 70 muestra que usted se calificaría como si mostrara una ambivalencia o disposición general mezclada hacia el pensamiento critico durante los últimos dos dias. 
Based on that rating form, we might assert the participants knew about the processes of thinking and employed them during their daily life. However, and during the training session, it was showed that students seemed to lack knowledge about critical thinking, and most importantly, they seemed to be unfamiliar with the process of thinking critically. The way they expressed their ideas and their explanations about questions related to critical thinking and its importance, personal opinions and learning strategies were the proof in which an important change emerged. For that reason, the training session became for the participants the right moment to start changing their minds, considering new points of view, understanding the differences and finding an objective to achieve when working with songs in the classroom.

An example of the participants' critical thinking awareness and the dynamics generated in the classroom is taken from the first video recording.

\section{Extract 3: \\ Teacher: How would you define CT? Student 1: Es como ir más allá de lo evidente? De lo que no es tan obvio?... Como adoptar una posición crítica frente a ciertas situaciones? (12:38) \\ Student 7: Es como buscarle el lado flaco al tema, debilidades ... si como debilidades. $\mathrm{Y}$ pues al hacer eso, empezar a dar argumentos... (13:00) Video recording. Session: 1}

In this extract it is evident that the training session exposed participants to a new situation in which it was unnecessary to have a strong knowledge about specific concepts but personal points of view about it were required.
Here the focus was on the awareness students needed to have about the concepts related to critical thinking, for that reason, the leading question asked by the teacher was not based on a song but based on a concept that students needed to approach to start an accurate process of critical thinking. When students had the chance of reflecting upon the importance of CT and common activities done by any kind of person, they allowed themselves to change the conception of the English class and began exchanging personal experiences.

The methodology adopted was the second important condition to conduct the activities in a flexible form. The participants received input, got in contact with a problem, worked alone and collaboratively, and finally, they expressed and concluded their ideas.

There were several relevant facts as part of a flexible methodology that favors a CT development: First, the use of oral and written discourse that opened more possibilities for the students to participate, be active and understand that everything they said was important and valuable. Second, individual work was characterized by personal and subjective perspectives about an issue, the participants approached the problem based on their own experience and backgrounds, however, when students worked collaboratively some of them revealed an enormous capacity of adaptation; they discussed and drew conclusions as a result of a mutual agreement. That was the big contribution of a combination of individual and collaborative work; all sessions long, the participants needed to get familiar 
with personal and external opinions before drawing plausible conclusions.

Oral Extract 4:

Teacher: So, what do you think about those videos? Did you find any fact?

Student 1: So, in the first video Juanes (cómo se dice eh... try) Trata de dar un mensaje. (29:43)

Teacher: What is the message for you?

Student 1: Las minas. (29:43)

Video recording

Written Extract 5:

The problem

Student 2: Que hasta una canción está mostrando la realidad de lo que vivimos. Que los comerciales solo sirven para vender cosas y no para solucionar problemas.

Students' process chart 1

Some participants expressed their empathy when they found in the sessions several options to give opinions. That means that those students who felt insecure when speaking, found with the student's process chart the possibility to write their concerns for them to systematically organize their ideas by following the PBL conditions. Also, most of the time those other students in favor of speaking were discussing upon an issue, listening to others and building knowledge.

\section{Critical Thinking Ladder}

The name of this subcategory depended on the differences and commonalities in the participants' critical thinking development. Most of them demonstrated a broad different critical thinking process; some others, shared common features observed under the view of The Holistic Critical Thinking Scoring Rubric designed by Facione (2013) in accordance with the levels of the six basic critical thinking skills. The six main CT skills observed and analyzed were: Interpretation, analysis, explanation, inference, evaluation and self-regulation. 


\title{
The Holistic Critical Thinking Scoring Rubric - HCTSR
}

\author{
A Tool for Developing and Evaluating Critical Thinking
}

Peter A. \& Noreen C. Facione

\begin{tabular}{|c|}
\hline $\begin{array}{l}\text { Strong } 4 \text {-- Consistently does all or almost all of the following: } \\
+ \text { Accurately interprets evidence, statements, graphics, questions, etc. } \\
+ \text { Identifies the most important arguments (reasons and claims) pro and con. } \\
\text { + Thoughtfully analyzes and evaluates major alternative points of view. } \\
\text { + Draws warranted, judicious, non-fallacious conclusions. } \\
\text { + Justifies key results and procedures, explains assumptions and reasons. } \\
+ \text { Fair-mindedly follows where evidence and reasons lead. }\end{array}$ \\
\hline $\begin{array}{l}\text { Acceptable } 3 \text {-- Does most or many of the following: } \\
+\quad \text { Accurately interprets evidence, statements, graphics, questions, etc. } \\
+\quad \text { Identifies relevant arguments (reasons and claims) pro and con. } \\
+\quad \text { Offers analyses and evaluations of obvious alternative points of view. } \\
+\quad \text { Draws warranted, non-fallacious conclusions. } \\
+\quad \text { Justifies some results or procedures, explains reasons. } \\
+\quad \text { Fair-mindedly follows where evidence and reasons lead. }\end{array}$ \\
\hline $\begin{array}{l}\text { Unacceptable } 2 \text {-- Does most or many of the following: } \\
+\quad \text { Misinterprets evidence, statements, graphics, questions, etc. } \\
+\quad \text { Fails to identify strong, relevant counter-arguments. } \\
+\quad \text { gnores or superficially evaluates obvious alternative points of view. } \\
+\quad \text { Draws unwarranted or fallacious conclusions. } \\
+\quad \text { Justifies few results or procedures, seldom explains reasons. } \\
+\quad \text { Regardless of the evidence or reasons, maintains or defends views } \\
\text { based on self-interest or preconceptions. }\end{array}$ \\
\hline $\begin{array}{l}\text { Weak 1-- Consistently does all or almost all of the following: } \\
\text { + Offers biased interpretations of evidence, statements, graphics, questions, } \\
\text { information or the points of view of others. } \\
+\quad \text { Fails to identify or hastily dismisses strong, relevant counter-arguments. } \\
+\quad \text { Ignores or superficially evaluates obvious alternative points of view. } \\
+\quad \text { Argues using fallacious or irrelevant reasons, and unwarranted claims. } \\
\text { Does not justify results or procedures, nor explain reasons. } \\
\text { + Regardless of the evidence or reasons, maintains or defends views } \\
\text { based on self-interest or preconceptions. }\end{array}$ \\
\hline
\end{tabular}

Table 5. CT scoring rubric taken from Facione (2013) 
Facione (2013) proposed the practical taxonomy that was appropriate following set of cognitive skills adding for this study because it provides criteria some dispositions. This is a complete and to classify each one of the categories.

\begin{tabular}{|c|c|}
\hline COGNITIVE SKILLS & DISPOSITIONS \\
\hline 1. Interpretation & \multirow{6}{*}{$\begin{array}{l}\text { Systematic } \\
\text { Inquisitive } \\
\text { Judicious } \\
\text { Truth seeking } \\
\text { Analytical } \\
\text { Open-minded }\end{array}$} \\
\hline 2. Analysis & \\
\hline 3. Explanation & \\
\hline 4. Inference & \\
\hline 5. Evaluation & \\
\hline 6. Self-regulation & \\
\hline
\end{tabular}

Table 6. CT skills and dispositions (Facione, 2013)

Facione's taxonomy (2013) was used to label students critical thinking processes taking advantage of the answers provided by the students that were classified according to the cognitive skills and particularities presented. The following rubric routed the study in accordance with the critical thinking levels in terms of cognition that students could achieve in the educational context based on a set of specific questions:

\begin{tabular}{|c|c|c|}
\hline Cognitive skill & \multicolumn{2}{|c|}{ Questions related to the skill } \\
\hline 1. Interpretation & $\begin{array}{l}\text { What is the main fact in ...? } \\
\text { What do you consider? } \\
\text { What are the main arguments? } \\
\text { What are the evidences and the } \\
\text { reasons? } \\
\text { What does this mean? }\end{array}$ & $\begin{array}{l}\text { What is happening? } \\
\text { How should we under- } \\
\text { stand this? } \\
\text { What is he best way to } \\
\text { categorize this? } \\
\text { How can we make } \\
\text { sense out of this? }\end{array}$ \\
\hline 2. Analysis & $\begin{array}{l}\text { Please tell us your reasons for } \\
\text { making that claim ... } \\
\text { What is your conclusion? } \\
\text { Why do you think that? }\end{array}$ & $\begin{array}{l}\text { What are the argu- } \\
\text { ments pro and con? } \\
\text { What is your basis for } \\
\text { saying that? }\end{array}$ \\
\hline 3. Explanation & $\begin{array}{l}\text { What were the specific findings? } \\
\text { Please tell us how you conduct- } \\
\text { ed that analysis? } \\
\text { How do you think that was the } \\
\text { best analysis or solution? }\end{array}$ & $\begin{array}{l}\text { How would you explain } \\
\text { why this particular de- } \\
\text { cision was made? } \\
\text { How did you come to } \\
\text { that interpretation? }\end{array}$ \\
\hline
\end{tabular}




\begin{tabular}{|l|l|l|}
\hline Cognitive skill & \multicolumn{2}{|c|}{ Questions related to the skill } \\
\hline \multirow{5}{*}{ 4. Inference } & $\begin{array}{l}\text { What are the conse- } \\
\text { Given what we know so far, } \\
\text { What conclusions we can draw? } \\
\text { What does this evidence imply? } \\
\text { If we accepted that assumption, } \\
\text { how would things change? }\end{array}$ & $\begin{array}{l}\text { What are some alterna- } \\
\text { thives we haven't yet ex- } \\
\text { plored? } \\
\text { Let's consider each op- } \\
\text { tion and see where it } \\
\text { takes us? }\end{array}$ \\
\hline \multirow{5}{*}{ Evaluation } & $\begin{array}{l}\text { How credible is that claim? } \\
\text { How strongare those arguments? } \\
\text { Why do you think we can trust } \\
\text { what this person claims? }\end{array}$ & $\begin{array}{l}\text { How confident can we } \\
\text { be in our conclusion? } \\
\text { Do you have our facts } \\
\text { right? }\end{array}$ \\
\hline \multirow{5}{*}{ Self-regulation } \\
& $\begin{array}{l}\text { Our in this issue is still too } \\
\text { vague, can we be more precise? } \\
\text { How good was our methodology } \\
\text { and how well did we follow it? }\end{array}$ & $\begin{array}{l}\text { How good is our evi- } \\
\text { dence? } \\
\text { Ok before we commit, } \\
\text { what are we missing? }\end{array}$ \\
\hline
\end{tabular}
Table 7. Questions to foster CT adopted from Facione (2013)

In order to illustrate the reader about the procedure that led the classification of the students' critical thinking process, it was necessary to observe and analyze three important components: First, The Holistic Critical Thinking Scoring Rubric; second, the statements transcribed from the videos and charts; third, the amount of entries registered from the videos and charts based on the students' interventions. The following chart explains the four basic stages used to conduct the analysis of the critical thinking process of the students:

\begin{tabular}{|c|l|}
\hline STAGES & \multicolumn{1}{c|}{ DESCRIPTION } \\
\hline STAGE 1 & $\begin{array}{l}\text { The Holistic Critical Thinking Scoring Rubric was the main } \\
\text { instrument employed to classify the CT level of the students. } \\
\text { On this rubric there were seven specific cognitive skills and } \\
\text { four CT levels: Strong, acceptable, unacceptable and weak. }\end{array}$ \\
\hline STAGE 2 & $\begin{array}{l}\text { The students' statements transcribed from the videos were } \\
\text { classified in accordance with the skills presented on the rubric. }\end{array}$ \\
\hline STAGE 3 & $\begin{array}{l}\text { According to the characteristics of the information and the } \\
\text { criteria presented on the rubric, the students interventions } \\
\text { were assigned a level in CT. }\end{array}$ \\
\hline STAGE 4 & $\begin{array}{l}\text { In order to observe those skills that had a stronger emphasis, } \\
\text { it was necessary to count the number of entries recorded from } \\
\text { the videos based on the characteristics of the interventions. }\end{array}$ \\
\hline
\end{tabular}

Table 8. Stages of analysis 
The following example represented the four stages mentioned before:

\begin{tabular}{|l|l|l|l|l|}
\hline Students & \multicolumn{1}{|c|}{$\begin{array}{c}\text { Stage 1 } \\
\text { Rubric }\end{array}$} & $\begin{array}{c}\text { Stage 2 } \\
\text { Characteristic of the } \\
\text { statement }\end{array}$ & $\begin{array}{c}\text { Stage 3 } \\
\text { CT Level }\end{array}$ & $\begin{array}{c}\text { Stage 4 } \\
\text { Emphasis }\end{array}$ \\
\hline $\begin{array}{l}\text { Students } \\
\text { that } \\
\text { answered } \\
\text { the } \\
\text { question } \\
18 / 21\end{array}$ & $\begin{array}{l}\text { Explanation } \\
\text { skill }\end{array}$ & $\begin{array}{l}\text { Leading question: } \\
\text { Do you have another } \\
\text { example with } \\
\text { addiction problems? }\end{array}$ & $\begin{array}{l}\text { Acceptable: } \\
\text { Answer: Amy } \\
\text { Jinifies } \\
\text { some } \\
\text { results or } \\
\text { procedures, La } \\
\text { encontraron muerta } \\
\text { por sobre dosis. }\end{array}$ & $\begin{array}{l}\text { Strong } \\
\text { emphasis } \\
\text { according } \\
\text { to the } \\
\text { entries }\end{array}$ \\
\hline
\end{tabular}

Table 9. Example of the stages of analysis

After analyzing common patterns and the data gathered from the video recordings and the students' artifacts (Charts), one may assert that the three CT skills with more emphasis during the development of the activities were: analysis, inference and explanation based on the frequency of entries registered on the videos and charts; However, the CT process were not exactly the same, they varied according to the activities, particularities of the task and the exchange of ideas in the collaborative work.

\begin{tabular}{|c|c|c|c|c|c|}
\hline EMPHASIS & CT SKILL & STRONG & ACCEPTABLE & UNACCEPTABLE & WEAK \\
\hline \multirow{3}{*}{$\begin{array}{l}\text { STRONG } \\
\text { EMPHASIS }\end{array}$} & ANALYSIS & & $\checkmark$ & & \\
\hline & INFERENCE & & $\checkmark$ & & \\
\hline & EXPLANATION & $\checkmark$ & & & \\
\hline \multirow{3}{*}{$\begin{array}{l}\text { WEAK } \\
\text { EMPHASIS }\end{array}$} & INTERPRETATION & & $\checkmark$ & & \\
\hline & SELF-REGULATION & & & $\checkmark$ & \\
\hline & EVALUATION & & $\boldsymbol{V}$ & & \\
\hline
\end{tabular}

Table 10. Results in CT skills.

\section{Music: One Word Many Routes}

After observing, grouping and analyzing the data there were three components that essentially explained the routes that music may provide to evidence a CT development process.
The routes were based on three aspects: Dynamics of the English class, English learning process and problem solving.

1. Dynamic of the English class. The contribution of music combined with problem-based activities in the 
students' CT process was evidenced when the students expressed their opinions about the dynamic of the class. Inskip and MacFarlane (2007) assert that the emotional component of music as part of the process of creation and understanding of meaning is absolutely important because it facilitates communication. Therefore, the dynamics generated with music opened a pleasant and active knowledge exchange, and of course, the participants started thinking of the English class as a different space to include the external reality into the classroom.

\section{Extract 6: ${ }^{3}$}

Question 2: Describe how was the atmosphere of the English class when using music in the resolution of a problem.

Student 5: "People tend to give up when things are the same all the time, but when musig is included in the class, students feel a different and much better atmosphere".

Student 14: "The environment was improved and became more dynamic and unusual. That was a good way of calling students' attention and fostering participation".

Survey

2. English learning process. In relation to the advantages of including music and problem-based activities in the English learning process, students' reflection was positive upon that particular issue. Barell (2003) claimed that the students think critically when a problem becomes the avenue that conducts the process of thinking. That situation is closely related to self-

3 The survey was done in the mother tongue and translated into English by the researcher. question and problem solving. The participants' comments about their personal improvement varied from simple vocabulary aspects to more elaborated facts such as: motivation increase, understanding of grammatical concepts and interest for using the language differently.

\section{Extract 7:4}

Question 1: How was your personal experience about the dynamics of the English class when using songs in the learning process?

Student 9: "For me, I had never seen something like that before. It is something new and creative. I think there are still difficult things for me in the process of learning and thanks to the activities I could improve those aspects".

Teacher: What did you improve?

Student 9: "My listening skill. The activities provided an opportunity for me to refine it and the process was dynamic and motivated students to learn".

Interview

3. Problem solving. The inclusion of problem-based activities based on songs in the English class was a positive and innovative aspect. "Students in a problem-based learning environment have to direct their own learning and carry out their own research in order to address the ill-structured problems they encounter" (Lie Lim, 2009, p. 172). That means that problems became the vehicle to conduct a personal and different thinking process in order to try to find a feasible solution. The participants explained the way in which that fact directly affected their conceptions

4 This part of the survey was translated into English by the researcher. 
about life. They expressed a particular development not only in the CT process but also in the acceptance of differences and knowledge construction and reconstruction based on opinions.

\section{Extract 8:}

Question 1: How was your personal experience about the dynamics of the English class when using songs in the learning process?

Student 1: "It was like the sum of different aspects. We needed to get familiar with the song and lyrics but also, we should provide opinions and that fact helped us set a position in front of a specific topic".

Question 6: How your personal motivation for learning a language was evidenced during the development of the sessions? Is it different now?

Student 13: Knowing that I can learn by myself is something that motivates me a lot.

Student 5: "I think it has changed because before, I was worry about a final score and that was why I tried to attend the class, and now it is interesting to come to class and try to solve different problems".

Interview

\section{Conclusions}

Music resulted to be the aspect that triggered students' capacity of analysis and CT development process. However, it was absolutely necessary the use of questions and attractive situations that made students think in order to activate the powerful content of music differently. Students liked the combination of individual and collaborative work, the options to communicate by writing or speaking and the aspects of analysis based on the content of songs, specifically, songs, videos, lyrics, biographies, interviews and images.

The participants evidenced different CT levels when they were immersed in problematic activities. In that same manner, the evidence of CT development depended not only on the capacities that students definitely had but also on the opportunities and vehicles the teacher provided to conduct organized and purposeful tasks. Music enormously contributed to students' CT development because it was employed as a rich source of the current reality, it changed the atmosphere of the English classroom, motivated students' participation and opened unexplored domains in the CT process through situational and problematic activities.

The execution of this project and the results achieved after analyzing data imply that there are more aspects with the necessity of being observed and researched. In this particular context, the implications refer to the importance of including critical thinking opportunities in any kind of activity the English teachers or others propose to deal with. That implication may conduct interesting and researchable practices. The development of the participants' language learning process could be observed or treated when working with problematic activities. In that same avenue, it will be worth to observe the incidence of a similar project in different kind of conditions and contexts where the desire is the employment of music as a meaningful source of learning. 


\section{References}

Barell, J. (2003). Developing More Curious Minds. Association for Supervision and Curriculum Development Alexandria, VA, USA. (ASCD).

Bell, J., and Waters, S. (2010). Doing your research project: A guide for first-time researchers in education, health and social science. England. McGraw Hill House.

Birjandi, P., and Bagherkazemi, M. (2010). The Relationship between Iranian EFL Teachers' Critical Thinking Ability and their Professional Success. English Language Teaching 3 (2), 135.

Bogdan, R. C., and Biklen, S. K. (1998). Qualitative research in education: An introduction to theory and methods (3rd ed.). Needham Heights, MA: Allyn \& Bacon.

Coghlan, D. (2004). Action Research in the Academy: Why and Whither? Reflections on the Changing Nature of Research 1. Irish Journal of Management 25 (2), 1.

Facione, P. (2013). Critical Thinking: What it is and why it counts. Retrieved from https://www.nyack.edu/ files/CT_What_Why_2013.pdf

Feldmand, D. (2009). Critical Thinking: Make Strategic decisions with confidence. USA: Azxo Press.
Fonseca, M., Toscano, C., and Wermke, K. (2011). Melodies that help: The Relation between Language Aptitude and Musical Intelligence. Anglistik International Journal of English Studies 22 (1), 101-118.

Freeman, D. (1990). Doing Teacher Research. Boston: Heinle $\mathcal{E}$ Heinle.

Halpern, D. (1998). Teaching critical thinking across domains: dispositions, skills, structure training, and metacognitive monitoring. American Psychologist 53 (4), 449-455.

Hill, K., and Robinson, N. (2003). Locomotion and literacy: Effective strategies to enhance literacy instruction. Retrieved from https://files.eric.ed.gov/ fulltext/ED474066.pdf

Hubbard, R., and Miller, B. (1999). Living the Questions: A Guide for Teachers Researchers. York, Maine: Stenhouse Publishers.

Iakovos, T. (2014). Critical and Creative Thinking in The English Language Classroom. International Journal of Humanities and Social Science 1 (8), 82-86.

Inskip, C., and MacFarlane, A. (2007). Meaning, communication, music: towards a revised communication model. Journal of Documentation, 64 (5), 687-706. 
Kennedy, V. (2014). Critical, Cultural and Multimodal Approaches to Using Songs as Literature in Language Learning. Libri and Liberi 3 (2), 295-310.

Kendall, F. (1996). Diversity in the classroom: New approaches to the education of young children. New York: Teachers College Press.

Nurius, P. S. (1995). Critical thinking: A meta-skill for integrating practice and information technology training. Human Services in the Information Age, 109-126.

Paquette, K., and Rieg, S. (2008). Using Music to Support the Literacy Development of Young English Language Learners. Early Childhood Education Journal, 36 (3), 227-232.

Patton, M. (2002). Qualitative research $\mathcal{E}$ evaluation methods ( $3 \mathrm{rd}$ edn.). Thousand Oaks CA: Sage.
Pineda, C. (2003). Searching for Improved EFL Classroom Environments. The Role of Critical Thinking-related Tasks. Colciencias.

Puthikanon, N. (2010). Examining Critical Thinking and Language Use through the Use of Webquests in an EFL Reading Class. USA: Proquest Dissertation Publishing.

Richards, K. (2009). Trends in Qualitative research in language teaching since 2000. Language Teaching 42 (2), 1-35.

Tseng, M. (2008). Data-driven problem solving and students' critical thinking in a problem based learning environment. ProQuest Dissertations and Theses.

Yuen, L (2011). A comparison of students' reflective thinking across different years in a problem-based learning environment. Instructional Science 39, 171-188. 